3 Levo Y, Gorevic P D, Kassab H J, Zucker-Franklin D, Franklin E C. Association between hepatitis B virus and essential mixed cryoglobulinemia. $N$ Engl J Med 1977; 296: 1501-4.

4 García-Bragado F, Villar M, Biosca M, Vilardell M, Jardi R, Allende E. Essential mixed cryoglobulinemia and chronic persistent hepatitis. $N$ Engl J Med 1985; 312: 187.

5 Reinherz E L, Schlossman S F. Regulation of the immune response inducer and suppressor T-lymphocyte subsets in human beings. $N$ Engl $J$ Med 1980; 303: 370-3.

6 Meroni P L, Barcellini W, De Bartolo G, Invernizzi F, Zanussi $\mathrm{Z}$. Abnormalities of in vitro immunoglobulin synthesis by peripheral blood lymphocytes from patients with essential mixed cryoglobulinemia. Clin Immunol Immunopathol 1984; 33: $245-57$.

7 Meroni P L, Ciboddo G F, Colombo G, Bonara P, Invernizzi F. T Cell defect in essential mixed cryoglobulinemia. Int Arch Allergy Appl Immunol 1979; 59: 308-14.

8 Meroni P L, Barcellini W, Messina K, De Bartolo G, Capsoni F, Invernizzi F. Defective suppressor cell activity in essential mixed cryoglobulinemia. J Clin Lab Immunol 1982; 8: 177-82.

\section{Systemic lupus erythematosus without clinical renal abnormalities}

SIR, We read with interest the study of O'Dell et al ${ }^{1}$ showing a high incidence of mesangial changes in renal biopsies from patients with systemic lupus erythematosus (SLE) without clinical renal abnormalities. They found no cases of focal or diffuse proliferative glomerulonephritis. These results are different from those previously reported by other authors ${ }^{23}$ and question the relevance of renal biopsy in these patients.

Recently we have performed renal biopsy in 13 patients with SLE (fulfilling the American Rheumatism Association revised criteria ${ }^{4}$ ) who had no clinical signs of renal involvement (no urinary sediment abnormalities, absence of proteinuria, and serum creatinine below $1.3 \mathrm{mg} / \mathrm{dl}(115$ $\mu \mathrm{mol} / \mathrm{l})$ ). All renal biopsy specimens were examined by two pathologists and categorised according to the modified classification proposed by the World Health Organisation. $^{5}$

Five cases $(38 \%)$ showed no histological or immunofluorescence changes (type I), six (46\%) patients had a mesangial nephropathy (three type IIa and three type IIb), and two $(15 \%)$ had a focal proliferative glomerulonephritis (type III). None of the patients had previous evidence of neurological abnormalities. Patients with normal renal biopsies (type I) only had arthritis, skin lesions, and Raynaud's phenomenon. In contrast, six patients with histological renal involvement had serositis or haemolytic anaemia. All cases with silent nephropathy were treated with steroids and showed a benign clinical course with stable renal function and absence of urinary abnormalities during follow up (one to 76 months, mean 27 months).

On the basis of these results we agree with O'Dell $e a^{\prime}{ }^{1}$ that, in the absence of clinical renal abnormalities, significant renal involvement is uncommon in SLE. However, as reported by Mahajan et $a l^{2}$ and Lehey et $a l^{3}$ and confirmed in the present study, a few patients may $\frac{}{\omega}$. have severe renal lesions requiring steroid therapy. Thus until more information becomes available we believe that a renal biopsy should be performed in those SLE patients presenting with clinical manifestations other than arthritis or cutaneous lesions since this policy may allow detection of silent nephritis lesions.

Servicio de Medicina Interna,

Hospital Clínico y Provincial,

Facultad de Medicina,

Barcelona, Spain

Servicio de Nefrologia,

Hospital Clínico y Provincial,

Facultad de Medicina,

Barcelona, Spain

\section{References}

1 O'Dell J R, Hays R C, Guggenheim S J, Steigerwald J C. Systemic lupus erythematosus without clinical renal abnormalities: renal biopsy findings and clinical course. Ann Rheum Dis 1985; 44: 415-9.

2 Mahajan S K, Ordoñez N G, Feitelson P J, Lim V S, Spargo B H, Katz A L. Lupus nephropathy without clinical renal involvement. Medicine (Baltimore) 1977; 56: 493-501.

3 Leehey D J, Katz A I, Azaran A H, Aronson A J, Spargo B H. Silent diffuse lupus nephritis: long-term follow up. Am J Kidney Dis 1982; 2 (suppl 1): 188-96.

4 Tam E M, Cohen A S, Fries J, et al. The 1982 revised criteria for the classification of systemic lupus erythematosus. Arthritis Rheum 1982; 25: 1271-7.

5 Finlander P, Koss M, Kitridou R, Border W A. Glomerulonephritis in systemic lupus erythematosus. Am J Nephrol 1981; 1: 53-67.

SIR, We appreciated the letter of Font et al and the opportunity to respond to it. The findings of Font $e t$ al that none of the 13 lupus patients without clinical evidence of renal disease had diffuse proliferative glomerulonephritis are very similar to our findings but very different from the findings of Mahajan et al. ${ }^{1}$ We were surprised that five of the 13 lupus patients in their study (Font et al) had completely normal renal biopsies. All of our patients, $\mathcal{O}$ despite the absence of clinical renal abnormalities, had $₹$ mesangial abnormalities as shown either by light micro- 0 scopy or by immunofluorescence studies. Our findings are similar to those of most other studies published in the literature, which show that most patients, despite the absence of clinical renal disease, have abnormalities on $N$ renal biopsies. ${ }^{1-4}$

We do not agree with the recommendation of Font et al that because they found focal proliferative glomeru- $\mathcal{N}$ lonephritis in two of their patients they would advocate $\underset{\sigma}{ }$ renal biopsies in lupus patients in the absence of clinical renal abnormalities. As stated in our paper there is no evidence in the literature to suggest that early treatment of $\cong$ histopathological abnormalities found on renal biopsy in the absence of clinical findings will in any way influence -0 prognosis. In fact, all studies in lupus nephritis that have $\underset{\mathbb{D}}{\vec{D}}$ looked at the question have concluded that clinical $\stackrel{\square}{\square}$ parameters are a much stronger indication of prognosis $\mathbb{Q}$ than histological classification. 
In summary, we agree with the findings of Font $e$ al that significant renal pathology in lupus patients without clinical renal abnormalities is rare, but we do not advocate renal biopsy in this group of patients.

Department of Internal Medicine, J R O'DELL. Section of Rheumatology and Immunology, University of Nebraska Medical Centre, Omaha, NE 68105, USA

\section{References}

1 Mahajan S K, Ordoñez N G, Feitelson P J, Lim V S, Spargo B H. Katz A L. Lupus nephropathy without clinical renal involvement. Medicine (Baltimore) 1977; 56: 493-501.

2 O'Dell J R, Hays R C, Guggenheim S J, Steigerwald J C. Systemic lupus erythematosus without clinical renal abnormalities: renal biopsy findings and clinical course. Ann Rheum Dis 1985; 44: 415-9.

3 Dillard M G, Tillman R L, Sampson C C. Lupus nephritis: correlations between clinical course and presence of electrondense deposits. Lab Invest 1975; 32: 261-9.

4 Houghton D, Bennett W, Bardana E, et al. Silent renal involvement in systemic lupus erythematosus. Kidney Int 1975; 8: 449 .

\section{Ankylosing spondylitis, HLA-B27, and klebsiella}

SIR, With particular reference to our studies ${ }^{12}$ and those of Ebringer and his associates, ${ }^{34}$ the article by Singh et al (p. 190 , this issue), attempts to address the controversial issue of cross reactivity between certain strains of klebsiella and the lymphocytes of HLA-B27 positive patients with ankylosing spondylitis $\left(\mathrm{B}_{2} 7^{+} \mathrm{AS}^{+}\right)$. Controversy is a healthy byproduct of scientific interest, and it is essential that our findings and those of other workers in the field be subjected to the closest scrutiny and evaluation. Those entering this debate, however, should do so with a sense of responsibility; presentation of data which are based on questionable or inadequately controlled techniques must be considered scientifically misleading. I refer specifically to the ${ }^{51} \mathrm{Cr}$ release technique used by Singh et al that attempts to reproduce the specific cytotoxicity of antiklebsiella sera for $\mathrm{B}^{2} 7^{+} \mathrm{AS}^{+}$cells. There are several important differences between their technique and ours, and their departure from our published methods passes without comment or justification. Firstly, the ${ }^{51} \mathrm{Cr}$ labelled cells are incubated simultaneously with antiserum and diluted complement for one hour at $37^{\circ} \mathrm{C}$. The more conventional method and the one favoured by our group is to incubate the radiolabelled cells with antiserum for 30 min at room temperature $\left(20-24^{\circ} \mathrm{C}\right)$ before adding neat complement for a further $60 \mathrm{~min}$ at the same temperature. Secondly, Singh et al complete their assay by adding to each tube $1.5 \mathrm{ml}$ of cold $0.9 \% \mathrm{NaCl}$. The significance of this cold saline step is not entirely clear. We have recently tested five $\mathrm{B}_{27} 7^{+} \mathrm{AS}^{+}$cells (which were positive with our ${ }^{51} \mathrm{Cr}$ release technique) according to the Singh method and we were unable to demonstrate cross reactivity between klebsiella K43 BTS1 and other enteric bacteria and the patients' lymphocytes. Furthermore, the failure of the
Singh method in our hands is due largely to the simultaneous, rather than sequential, addition of antiserum and complement. Singh et al justify their choice of this unconventional cytotoxicity technique by pointing out that ... 'high levels of cytotoxicity were obtained against the lymphocytes in control tests with antilymphocytic serum'. However, most antilymphocytic sera are active in the absence of complement and since details on the production and source of this reagent are not given in the paper one assumes that the success of their assay technique rests largely on the activity of an alloantiserum, anti-HLA-B27.

We have been concerned by the non-confirmatory reports of this work and in an attempt to identify some of the factors which might contribute to the failure of others to confirm our findings we have recently completed a double blind trial involving $\mathrm{B}^{2} 7^{+} \mathrm{AS}^{+}$cells from a New Zealand population. ${ }^{5}$ This successful study, together with two previous confirmatory reports (in preparation), ${ }^{6}$ suggests that the phenomenon of 'cross reactivity' between enteric bacteria and $\mathrm{B}_{2} 7^{+} \mathrm{AS}^{+}$cells is not simply an Antipodean curiosity. ${ }^{7}$ Although many aspects of this controversy remain to be resolved, it is worth noting that of the non-confirmatory reports only Beaulieu et $a \boldsymbol{l}^{\boldsymbol{\beta}}$ have adhered to our published methods, while other workers found it necessary to modify one or more parameters of the ${ }^{51} \mathrm{Cr}$ release assay.

Blood Transfusion Centre, A F GECZY Australian Red Cross Society, 153 Clarence Street,

Sydney,

NSW 2000,

Australia

\section{References}

1 Geczy A F, Alexander K, Bashir H V, Edmonds J P, Upfold L I, Sullivan J. HLA-B27, Klebsiella, and ankylosing spondylitis: biological and chemical studies. Immunol Rev 1983; 70: 23-50.

2 Prendergast J K, Sullivan J S, Geczy A F, et al. Possible role of enteric organisms in the pathogenesis of ankylosing spondylitis and other seronegative arthropathies. Infect Immun 1983; 41: 935-41.

3 Welsh J, Avakian H. Cowling P, et al. Ankylosing spondylitis, HLA-B27 and Klebsiella. I. Cross-reactivity studies with rabbit antisera. Br J Exp Pathol 1980; 61: 85-91.

4 Ebringer A. The cross-tolerance hypothesis, HLA-B27 and ankylosing spondylitis. $\mathrm{Br} J$ Rheumatol 1983; 22 (suppl 2): 53-66.

5 McGuigan L E, Geczy A F, Prendergast J K, Edmonds J P, Hart H H, Bashir H V. The HLA-B27 associated cross-reactive marker on the cells of New Zealand patients with ankylosing spondylitis. Ann Rheum Dis 1986; 45: 144-8.

6 Archer J R, Stubbs M M, Currey H L F, Geczy A F. Antiserum to Klebsiella K43 BTS 1 specifically lyses lymphocytes of HLA-B27 positive patients with ankylosing spondylitis from a London population. Lancet 1985; i: 344-5.

7 Geczy A F, Prendergast J K, McGuigan L E, Upfold L I, Sullivan J S. Cross-reactivity of anti-Klebsiella K43 BTS 1 serum and lymphocytes of patients with ankylosing spondylitis: antipodean curiosity? Lancet 1985; i: 1169.

8 Beaulieu A D, Rousseau F, Israel-Assayag E, Roy R. Klebsiella related antigens in ankylosing spondylitis. J Rheumatol 1983; 10: 102-5. 